\title{
KEMANDIRIAN GURU SEKOLAH DASAR : STUDI REALITAS KEMANDIRIAN GURU SEKOLAH DASAR LULUSAN UNIVERSITAS TERBUKA DI DAERAH BOJONEGORO
}

\author{
Adi Suparto, Mujadi \\ Universitas Terbuka \\ E-mail : minovma@ecampus.ut.ac.id \\ http://doi.org/10.21107/pmt.v11i2.4770
}

\begin{abstract}
Abstrak
Kualitas pendidikan sangat bergantung pada siapa yang menjalankan pendidikan itu sendiri. Tingkat prestasi siswa juga sangat tergantung pada kualitas guru yang melakukan pembelajaran kepada peserta didik. Pendidikan di Indonesia telah membuat paradigma baru dalam mengatasi rendahnya kualitas pendidikan dan prestasi peserta didik melalui peningkatan kualifikasi akademik bagi guru yang mengajar di sekolah dasar hingga tingkat sekolah menengah. Untuk mewujudkan ini satu-satunya alternatif adalah Universitas Terbuka sebagai lembaga pendidikan tinggi jarak yang dapat menampung sejumlah besar siswa tanpa dibatasi oleh ruang dan waktu. Hal ini karena Universitas Terbuka menggunakan sistem pembelajaran jarak jauh dengan konsep belajar mandiri, sehingga guru yang belajar di Universitas Terbuka tidak harus meninggalkan pekerjaannya sebagai guru dalam proses pembelajaran.
\end{abstract}

Kata Kunci : pendidikan, kualitas, universitas terbuka, guru

\section{PENDAHULUAN}

Kualifikasi guru SD sangat erat kaitannya dengan kesiapan sumber daya manusia (SDM) yang berkualitas untuk meningkatkan mutu pendidikan di Indonesia. Sumber daya manusia sebagai guru haruslah mampu mengejawantahkan kurikulum tingkat satuan pendidikan (KTSP) yang berlaku. Jika seorang guru belum mampu mengejawantahkan KTSP, maka akan terjadi hambatan yang sangat signifikan dari segi kemandirian guru dalam menjalankan proses pembelajaran. Guru akan terpaku oleh rutinitas buku pelajaran yang ada, sementara siswa memerlukan materi pelajaran yang mampu memberikan wawasan lebih luas, sehingga kemampuan dan penguasaan materi oleh siswa menjadi terhambat dan mutu pendidikan jalan ditempat.

Sebagai konsekuensi logis dari rendahnya kualifikasi akademik akan berdampak pada pengembangan kemandirian dan kemampuan guru dalam menterjemahkan KTSP menjadi kurang optimal. Hasil dari pengamatan di lapangan setidak-tidaknya terdapat beberapa kelemahan-kelamahan yang diakibatkan oleh rendahnya kualifikasi guru sekolah dasar, di antaranya adalah sebagai berikut: 1. SDM (guru) kurang mampu menjabarkan KTSP pada kebanyakan satuan pendidikan yang ada. Pola penerapan KTSP atau kurikulum terbentur pada masih rendahnya kualitas guru di sekolah. Sebagian besar guru belum bisa diharapkan memberikan kontribusi pemikiran dan ide-ide kreatif untuk menjabarkan panduan kurikulum (KTSP), baik di atas kertas maupun di depan kelas. Selain disebabkan oleh rendahnya kualifikasi, juga disebabkan pola kurikulum lama yang terlanjur mengekang kreativitas guru.

2. Sumber Daya Manusia (guru) kurang mampu memberikan motivasi siswa untuk lebih berkreatif, terampil, dan inovatif pada meteri pelajaran ( IPA) yang selalu memanfaatkan sarana dan prasarana seperti alat peraga, laboratorium serta fasilitas penunjang yang menjadi syarat utama pemberlakuan KTSP. Baik guru maupun siswa sama-sama tidak mampu menghasilkan inovasi-inovasi baru (no innovation) 
3. Masih banyak guru yang belum memahami KTSP secara komprehensif baik konsepnya, penyusunannya maupun prakteknya di lapangan. Masih rendahnya kuantitas guru yang diharapkan mampu memahami dan menguasai KTSP dapat disebabkan karena pelaksanaan sosialisasi masih belum terlaksana secara menyeluruh. Jika tahapan sosialisasi tidak dapat tercapai secara menyeluruh, maka pemberlakuan KTSP secara nasional tidak memenuhi target dan tidak memungkinkan untuk dapat dicapai.

Kemandirian guru hendaknya terinduksi oleh kualifikasi akademik yang sepadan dan terukur, sehingga peluang untuk berkembang menjadi seorang profesional amat sangat terbuka. Membentuk guru yang berkualitas dalam kemandirian diperlukan waktu, keseriusan, dan pendidikan yang sesuai, apalagi pada era globalisasi saat ini. Undang-Undang Republik Indonesia nomor 14 tahun 2005 tentang guru dan dosen Bab IV Guru, Bagian kesatu; Kualifikasi, Kompetensi, dan Sertifikasi yang berbunyi:

1. Pasal 8 : Guru wajib memiliki kualifikasi akademik, kompetensi, sertifikat pendidik, sehat jasmani dan rohani, serta memiliki kemampuan untuk mewujudkan tujuan pendidikan nasional.

2. Pasal 9 : Kualifikasi akademik sebagaimana dimaksud dalam Pasal 8 diperoleh melalui pendidikan tinggi program sarjana atau program diploma empat.

Solusi baru yang dapat mempercepat peningkatan kualifikasi guru-guru SD tanpa menghambat kinerja pembelajaran di sekolah, sehingga tidak ada lagi kelas kosong maupun siswa yang ditelantarkan, dan proses pembelajaran tetap berjalan sebagaimana mestinya. Guru-guru SD dipicu untuk dapat bekerja dan belajar tanpa harus menghilangkan tanggungjawab sebagai pendidik. Bekerja dan belajar secara mandiri itulah yang akhirnya menjadi dasar pengambil kebijakan dan keputusan didaerah dari tingkat provinsi sampai tingkat Kab/Kota. Suatu kebijakan yang harus diterima oleh setiap guru SD untuk tetap melakukan proses pembelajaran di sekolah, dan meningkatkan kualifikasi Strata satu (S1) PGSD di perguruan tinggi.

Memperhatikan

beberapa

permasalahan tersebut diatas, peneliti mencoba untuk melakukan penelitian dengan pemilihan wilayah Kabupaten Bojonegoro sebuah kabupaten yang ada di Jawa Timur. Peneliti melihat perkembangan mutu pendidikan di Kabupaten Bojonegoro menggambarkan grafik yang sangat memuaskan dari tahun ke tahun. Gerakan Ayo Sekolah (GAS ) yang dislogankan memberikan daya tarik dan daya pikat tersendiri dihati masyarakat untuk mensukseskannya. Hal ini dapat dibuktikan sejak diluncurkannya program GAS yang disambut positif oleh warga Bojonegoro pada tahun 2014/2015 minat warga yang mengikuti program kejar paket $A$, paket $B$, dan paket $C$ mengalami perkembangan yang sangat signifikan.

Adapun jumlah guru-guru yang ada di tingkat sekolah yang ada pada tahun 2015/2016, yaitu; populasi guru SD sebanyak 6355 orang, populasi guru SMP sebanyak 2429 orang, dan populasi guru SMU sebanyak 2524 orang. Data dari Dinas Pendidikan Kabupaten Bojonegoro jumlah guru SD yang ada, yaitu guru sekolah dasar (SD) sebanyak $\pm 60 \%$ adalah berkualifikasi Strata Satu (S1) PGSD dari PTJJ Universitas Terbuka. Sedangkan untuk guru SMP dan SMU kualifikasi S1 dari PTJJ, yaitu Universitas Terbuka hanya mencapai $\pm 5 \%$. Dengan kemajuan dan perkembangan perkembangan yang sangat signifikan serta dilandasi dengan kemandirian dalam bekerja, data guru SD berkualifikasi S1 PGSD dari PTJJ-UT mendominasi $60 \%$ dari populasi guru SD yang ada di Kabupaten Bojonegoro. Dengan proporsi yang cukup besar guru-guru SD di Kabupaten Bojonegoro memberikan arti yang cukup besar pula dalam memajukan pendidikan dan meningkatkan mutu pendidikan, khususnya di sekolah dasar. Besarnya proporsi guru SD lulusan PTJJ Universitas Terbuka, dan pengalaman belajar mandiri yang berinisiatif sebagai mahasiswa Universitas Terbuka mampu membentuk kemandirian guru lulusan S1 PGSD Universitas Terbuka serta membawa kemajuan dan meningkatkan mutu pendidikan sekolah dasar. 
Berdasarkan pengalaman belajar sebagai mahasiswa S1 PGSD Universitas Terbuka yang memegang teguh pola belajar mandiri, dan sekarang telah menjadi guru tentu penerapan mandiri dalam tugasnya akan mengalami pergeseran atau perubahan arti sesuai dengan situasi, kondisi dan kebutuhan lapangan pekerjaan yang sangat menantang. Aktivitas sekarang sangatlah berbeda dengan masa sebagai mahasiswa S1 PGSD Universitas Terbuka yang sangat individualis. Kata mandiri perlu dikembangkan sedemikian rupa sehingga bukan hanya untuk diri sendiri saja, lebih luas lagi implementasi dalam proses pembelajaran. Melihat animo masyarakat yang sangat luar biasa dalam memilih dan memastikan untuk mencerdaskan diri melalui pendidikan dengan sistem terbuka jarak jauh, sumbangsih lulusan dari PTJJ-UT telah banyak menempati lembaga-lembaga formal dan non formal yang ada di Kabupaten Bojonegoro, serta tidak ketinggalan bahwa lulusan PTJJ-UT yang ada telah ikut berpartisipasi aktif dalam setiap pembangunan daerah. Beberapa pertimbangan atau alasan pemilihan lokasi dan hasil pengamatan sementara dari tahun 2005 sampai dengan 2015, diantaranya;

1. Jumlah guru lulusan PTJJ S1 PGSDUT sampai tahun 2016 di Kabupaten Bojonegoro semakin meningkat hingga mencapai > 3000 orang

2. Universitas Terbuka di Kabupaten Bojonegoro adalah salah satu perguruan tinggi negeri dalam bentuk POKJAR (kelompok belajar) yang telah mendapatkan kepercayaan oleh masyarakat maupun instansi pemerintah

3. Lulusan PTJJ S1 PGSD-UT di Kabupaten Bojonegoro mampu mewujudkan peningkatan mutu pendidikan di sekolah dasar

4. Kemandirian guru-guru lulusan S1 PGSD PTJJ_UT di Kabupaten Bojonegoro meningkat secara signifikan

5. Guru-guru lulusan PTJJ S1 PGSD-UT secara umum telah memperlihatkan kinerja yang meningkat dan lebih baik di bidang pendidikan
6. Guru-guru lulusan PTJJ S1 PGSD-UT di Bojonegoro merupakan salah satu pilar mewujudkan kesejahteraan dan pembangunan di Kabupaten Bojonegoro

7. Guru-guru lulusan PTJJ S1 PGSD-UT di Kabupaten Bojonegoro telah tersebar dan menempati SD swasta maupun SDNegeri baik di pedesaan maupun di perkotaan, serta kabupaten-kabupaten yang ada di sekitarnya

8. Kiprah guru-guru lulusan PTJJ S1 PGSD-UT di masyarakat, lembaga masyarakat, dan di lembaga pemerintahan merupakan sumberdaya manusia yang memberikan andil besar dalam menggerakkan pembangunan secara berkelanjutan di Kabupaten Bojonegoro

9. Populasi maupun sampel guru-guru lulusan S1 PGSD-UT yang ada merupakan bentuk yang sangat representatif sebagai pengambilan data

10. Sekolah dasar (SD) yang ada di Kabupaten Bojonegoro di mana didalamnya terdapat guru-guru lulusan S1 PGSD dari PTJJ UT secara kontinyu telah menjadi sekolah dasar teladan di tingkat Provinsi Jawa Timur.

\section{- Rumusan Masalah}

1. Bagaimana kemandirian menurut Guru Sekolah Dasar lulusan S1 PGSD Universitas Terbuka di Kabupaten Bojonegoro?

2. Bagaimana bentuk kemandirian pembelajaran IPA menurut Guru Sekolah Dasar lulusan S1 PGSD Universitas Terbuka di Kabupaten Bojonegoro?

\section{- Tujuan Penelitian}

1. Menganalisis kemandirian guru sekolah dasar lulusan S1 Pendidikan Tinggi Terbuka Jarak Jauh (PTJJ) Universitas Terbuka di Kabupaten Bojonegoro.

2. Menganalisis bentuk kemandirian IPA di sekolah dasar oleh guru-guru lulusan $\mathrm{S} 1$ PGSD Universitas Terbuka di Kabupaten Bojonegoro. 
METODOLOGI

- Landasan Teoritis

Penelitian ini merupakan penelitian kualitatif dengan landasan teoritis yang bertumpu secara mendasar pada fenomenologi, oleh karena itu fenomenologi dijadikan sebagai dasar teoritis yang utama sedang yang lainnya dijadikan sebagai dasar tambahan yang melatar belakangi secara teoritis penelitian kualitatif Moleong (2015).

Penelitian kualitatif mempunyai dua tujuan utama, yang pertama yaitu, menggambarkan dan mengungkap ( to describe and explore) dan kedua menggambarkan dan menjelaskan (to describe and explaim). Pada penelitian kualitatif, teori dibatasi pada pengertian: suatu pernyataan sistematis yang berkaitan dengan seperangkat proposisi yang berasal dari data dan diuji kembali secara empiris. Bogdan dan Biklen (1982) dalam Moleong (2015) menyatakan bahwa salah satu ciri dari penelitian kualitatif menggunakan metode kualitatif, yaitu; pengamatan, wawancara, atau penelaahan dokumen.

Pendekatan fenomenologi dengan menggunakan paradigma interpretative dapat memandang realitas sosial sebagai sesuatu yang holistik (utuh), kompleks, dinamis, penuh dengan makna dan hubungan gejala interaktif (reciprocal). Istilah fenomenologi sering digunakan sebagai anggapan umum untuk menunjukkan pada pengalaman subyektif dari berbagai jenis dan tipe subyek yang ditemui. Dalam arti yang lebih khusus, istilah ini mengacu pada penelitian terdisiplin tentang kesadaran dari perspektif pertama seseorang (Moleong, 2009). Fenomenologi merupakan pandangan berpikir yang menekankan pada fokus kepada pengalamanpengalaman subyektif manusia dan interpretasi-interpretasi dunia. Penelitian lapangan ( field research) dapat juga dianggap sebagai pendekatan luas dalam penelitian kualitatf atau sebagai metode untuk mengumpulkan data kualitatif. Ide pentingnya adalah bahwa peneliti berangkat ke lapangan untuk mengadakan pengamatan tentang sesuatu fenomenon dalam suatu keadaan alamiah atau "in situ". Dalam hal demikian maka pendekatan ini terkait erat dengan pengamatan berperan serta. (Moleong, 2015). Totalitas kemandirian yang dimiliki oleh seseorang atau guru secara ideal, terfokus pada kompetensi sebagai berikut; 1.Kompetensi Tanggungjawab

2.Kompetensi Inisiatif

3.Kompetensi Kemampuan

4.Kompetensi Kepuasan

5.Kompetensi Perencanaan.

\section{- Analisis Data}

Dalam menganalisis data penelitian ini, penulis menggunakan teknik analisis deskriptif kualitatif, dimana teknik ini penulis gunakan untuk menggambarkan, menuturkan, melukiskan serta menguraikan data yang bersifat kualitatif yang telah penulis peroleh dari hasil pengumpulan data. Analisis data kualitatif menurut Bogdan \& Biklen (1982) dalam Moleong (2015), yaitu upaya yang dilakukan dengan jalan;

1. Bekerja dengan data, mengorganisasikan data

2. Memilah-milahnya menjadi satuan yang dapat dikelola

3. Mensintesiskannya

4. Mencari dan menemukan pola

5. Menemukan apa yang terpenting dipelajari

6. Memutuskan apa yang dapat diceritakan kepada orang lain.

Adapun langkah yang digunakan peneliti untuk menganalisa yaitu:

1. Mencatat dan menelaah seluruh hasil data yang diperoleh dari berbagai sumber, yaitu dari wawancara, observasi dan dokumentasi.

2. Memanfaatkan mengumpulkan, memilah-milah, mensintesiskan, membuat ikhtisar dan mengklasifikasikan data sesuai dengan data yang dibutuhkan untuk menjawab rumusan masalah.

3. Mencari makna, hubungan-hubungan, dan membuat temuan-temuan umum terkait dengan rumusan masalah. 


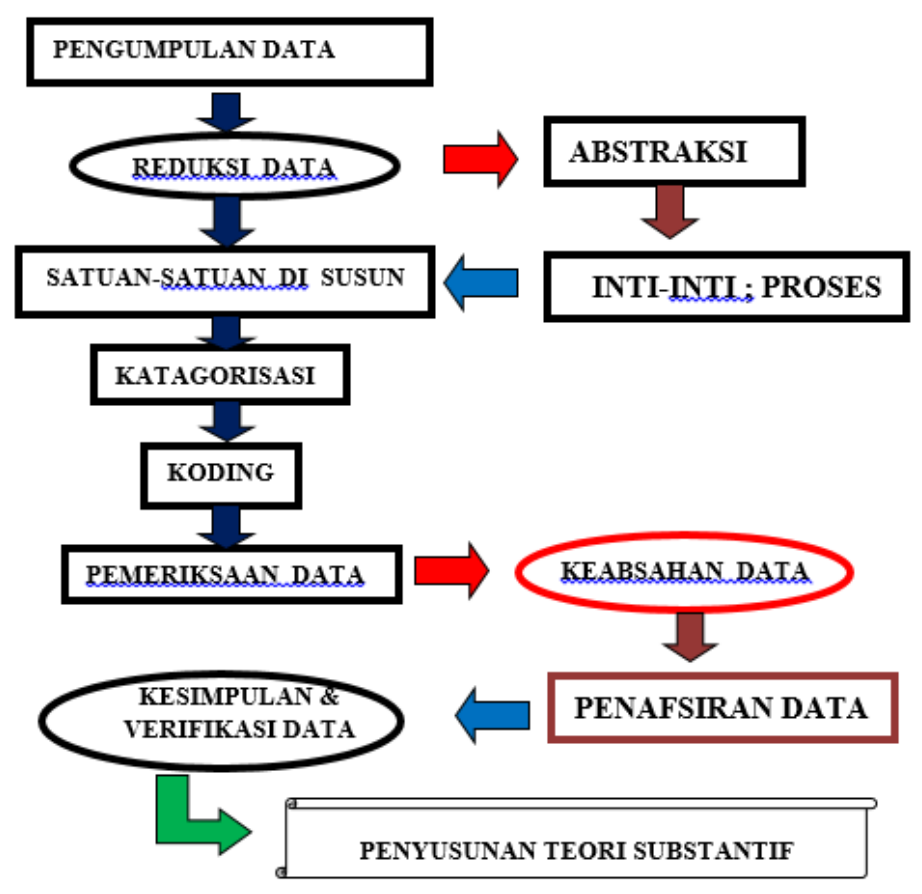

Gambar 1. Keranaka Analisis Data

\section{HASIL DAN PEMBAHASAN}

Kemandirian merupakan kemampuan seseorang untuk mewujudkan suatu keinginan atau kehendak tanpa meminta bantuan orang lain. Salah satu sikap yang wajib dimiliki oleh seorang guru karena mendasari keberhasilan sebuah pendidikan. Bagaimana tidak, gurulah yang menjadi sentral pelaksana pendidikan. Sebagai pelaksana pendidikan guru mempunyai tugas yang sangat penting yaitu bertugas membimbing dan mengarahkan peserta didik agar bisa tumbuh dan berkembang secara optimal. Pengertian mandiri berarti mampu bertindak sesuai keadaan tanpa meminta atau tergantung pada orang lain.

Berdasarkan hasil yang didapat dari pengamatan, pemantauan terhadap proses pembelajaran guru dan wawancara terhadap linforman pada sekolah dasar SDN Mulyo Agung 1, SDN Bubulan 1, SDN Sumber Bendo 1, dan SDN Cancung 1, tentang kemandirian guru dalam proses pembelajaran dan di masyarakat mempunyai bentuk-bentuk yang sangat bergam dan konditional. Namun ciri-ciri kemandirian terekam dalam indikatorindikator kemandirian itu sendiri. Berdasarkan uraian yang telah dikemukakan oleh para ahli tentang pengertian kemandirian, konsep kemandirian menurut Lerner (1976), Ryan et.al (1993) tentang kemampuan untuk mengatur dan menyeleksi tingkah laku, membimbing keputusan, serta berani bertanggungjawab atas keputusannya. Demikian juga ditinjau dari ciri-ciri kemandirian menurut Zakiyah (2000), Spencer dan Jass dalam Ali (2005), Antonius dalam Fatimah (2003), dan Steinberg \& Hill (1993) yang menyatakan bahwa seseorang yang mandiri adalah orang yang percaya diri akan kemampuan, dan memiliki prinsip dalam hidupnya tanpa bergantung pada orang lain.

Selanjutnya aspek-aspek kemandirian menurut Masrun dalam Widayatie (2009), Lamman er.al (1998) dan para pemikir sosiologi seperti Emile Durkheim, serta kemandirian guru dalam proses pembelajaran tersebut diatas peneliti menyusun totalitas kemandirian yang dimiliki oleh seseorang atau guru secara ideal, terfokus pada indikator-indikator:

1. Tegas dan rasa tanggungjawab.

2. Kemamampuan mengambil inisiatif.

3. Percaya akan kemampuannya (membuat/mengembangkan).

4. Kemampuan menyelesaikan persoalan dalam tugasnya.

5. Kemampuan mengatasi rintangan dari lingkungan masyarakat. 
6. Memperoleh kepuasan dari hasil kerjanya.

7. Penuh ketekunan dalam mengarahkan tingkah laku seseorang menuju keberhasilan.
8. Kemampuan menetapkan strategi (merencanakan) sendiri mewujudkan keinginan dan tujuannya.

a. Kompetensi Tanggungjawab : Pengamatan dan Pemantauan Peneliti

1. Tegas dan Rasa Tanggung Jawab

\begin{tabular}{|c|l|}
\hline No Temuan & \multicolumn{1}{|c|}{ Penjelasan } \\
\hline 1 & $\begin{array}{l}\text { Pemberian pengayaan/peer tutoring diberikan saat proses pembelajaran berjalan, } \\
\text { dan tambahan pelajaran setelah jam pelajaran usai pada siswa yang } \\
\text { kurang/terhambat. }\end{array}$ \\
\hline 2 & $\begin{array}{l}\text { Komunikasi dengan wali murid terjadi setiap hari saling bertukar informasi tentang } \\
\text { kemajuan peserta didik dan hasrat belajar dirumah maupun disekolah. }\end{array}$ \\
\hline 3 & $\begin{array}{l}\text { Jam dinding dibawa ke dalam kelas untuk memberikan penjelasan yang lebih } \\
\text { bermakna dari pada berceramah, serta meningkatkan hasrat belajar siswa. }\end{array}$ \\
\hline Proposisi 1 & $\begin{array}{l}\text { Kerja keras dan tanggungjawab di wujudkan dalam pemberikan tambahan } \\
\text { pelajaran di luar jam pelajaran bagi siswa yang mengalami hambatan akademik } \\
\text { dengan memberikan kegiatan ekstrakurikuler untuk meningkatkan hasrat dan } \\
\text { prestasi belajar peserta didik dengan dukungan wali murid, dan sekolah }\end{array}$ \\
\hline
\end{tabular}

2. Kemampuan Mengambil Inisiatif

\begin{tabular}{|c|l|}
\hline No Temuan & \multicolumn{1}{|c|}{ Penjelasan } \\
\hline 5 & $\begin{array}{l}\text { Kegiatan transfer of knowledge dilakukan melalui motivasi belajar, penanaman } \\
\text { nilai (values) melalui kerja kelompok, dan membangun karakter (character building) } \\
\text { melalui kepramukaan. }\end{array}$ \\
\hline 6 & $\begin{array}{l}\text { Kemajuan belajar siswa dipantau pada setiap proses pembelajaran berlangsung, } \\
\text { guru memberikan tugas, bertanya, memberikan tes, dan menilai. }\end{array}$ \\
\hline 8 & $\begin{array}{l}\text { Pemberian bimbingan secara klasikal maupun secara perorangan pada siswa saat } \\
\text { pulang sekolah dan mendapat persetujuan dari sekolah tanpa dipungut biaya }\end{array}$ \\
\hline Proposisi 2 & $\begin{array}{l}\text { Komunikasi dijalin secara aktif antara guru dan wali murid dilakukan setiap } \\
\text { pengambilan rapor siswa ke sekolah yang di prakarsai oleh Komite sekolah yang } \\
\text { membicarakan banyak hal masalah siswa. }\end{array}$ \\
$\begin{array}{l}\text { Guru tidak hanya menjalankan fungsi alih ilmu pengetahuan (transfer of } \\
\text { knowledge), tapi berfungsi juga menanamkan nilai (value), dan menbangun } \\
\text { karakter (Character building), sehingga proses belajar berjalan lancar }\end{array}$ \\
\hline
\end{tabular}

3. Percaya akan Kemampuannya

\begin{tabular}{|c|l|}
\hline No Temuan & \multicolumn{1}{c|}{ Penjelasan } \\
\hline 9 & RPP dikembangkan, guru sesuai dengan kebutuhan dan karakteristik siswa \\
\hline 10 & $\begin{array}{l}\text { Disiplin dan percaya diri mampu menyelesaikan tugas dengan baik, efisien dalam } \\
\text { pembelajaran serta produktif }\end{array}$ \\
\hline 11 & $\begin{array}{l}\text { Kebebasan dan kecerdasan guru mampu menjabarkan standar kompetensi dan } \\
\text { kompetensi dasar, sehingga siswa mampu meningkatkan pemahaman , } \\
\text { keterampilan, dan motivasi belajarnya }\end{array}$ \\
\hline 12 & $\begin{array}{l}\text { Kepercayaan dibangun dengan masyarakat melalui komunikasi dan hubungan } \\
\text { sosial yang baik, dengan cara mengerti permasalahan seseorang dari sudut } \\
\text { pandangnya, dan memberikan solusinya. }\end{array}$ \\
\hline Proposisi 3 & $\begin{array}{l}\text { kemampuan dan kelemahan siswa selalu dicatat setiap pembelajaran selesai, } \\
\text { untuk mengembangkan potensi yang sesuai dengan kegiatan-kegiatan } \\
\text { pembelajaran }\end{array}$ \\
$\begin{array}{l}\text { Kepercayaan dan hubungan yang baik dengan masyarakat, kebebasan, dan } \\
\text { kemampuan guru yang ada, mampu mengembangkan dan membuat RPP yang } \\
\text { lebih efektif dan sesuai dengan kebutuhan karakteristik sekolah/masyarakat/siswa. }\end{array}$ \\
\hline
\end{tabular}


4. Kemampuan Menyelesaikan Persoalan dalam Tugasnya

\begin{tabular}{|c|l|}
\hline No Temuan & \multicolumn{1}{c|}{ Penjelasan } \\
\hline 14 & $\begin{array}{l}\text { Kreatifitas dibangun dalam bentuk inovasi pembelajaran dengan memanfaatkan } \\
\text { kebun sebagai sumber belajar baru pada materi biologi dan mempraktekan cara } \\
\text { menyetek, menempel antar tumbuhan pada siswa. }\end{array}$ \\
\hline 15 & $\begin{array}{l}\text { Mengembangkan media pembelajaran "angka" dan "jumlah" dengan menggunakan } \\
\text { bahan dan alat yang sederhana dan tersedia di lingkungan sebagai sumber belajar } \\
\text { yang mudah dimengerti dan menarik. }\end{array}$ \\
\hline 16 & $\begin{array}{l}\text { Simulasi gerhana matahari dengan menggunakan siswa adalah bentuk nyata } \\
\text { inovasi pembelajaran karena belum tersedianya alat peraga dalam pembuktian } \\
\text { konsep pelajaran. }\end{array}$ \\
\hline
\end{tabular}

5. Kemampuan Mengatasi Rintangan dari Masyarakat

\begin{tabular}{|c|l|}
\hline No Temuan & \multicolumn{1}{|c|}{ Penjelasan } \\
\hline 17 & $\begin{array}{l}\text { Keluhan masyarakat tentang siswa yang kurang mampu, dan nakal, diwujudkan } \\
\text { dalam bentuk memberikan tambahan pelajaran atau les di sekolah maupun di } \\
\text { rumah guru. }\end{array}$ \\
\hline 18 & $\begin{array}{l}\text { Tokoh masyarakat didatangakan untuk menjalin keakraban guru dan masyarakat } \\
\text { untuk memberikan ceramah di sekolah guna menunanjang tercapainya tujuan yang } \\
\text { diinginkan. }\end{array}$ \\
\hline 19 & $\begin{array}{l}\text { Anggota masyarakat yang mempunyai minat dan perhatian terhadap sekolah mau } \\
\text { membantu pendidikan; misal membantu barang-barang keperluan sekolah } \\
\text { diberikan melalui Komite Sekolah. }\end{array}$ \\
\hline Proposisi 4 & $\begin{array}{l}\text { Membangun komunikasi dengan masyarakat secara aktif dan saling percaya diri } \\
\text { mampu menyelesaikan persoalan pendidikan secara inklusif, inovatif dan } \\
\text { membangun prestasi dan citra pendidikan lebih baik. }\end{array}$ \\
\hline
\end{tabular}

6. Memperoleh Kepuasan dari Hasil Kerjanya

\begin{tabular}{|c|l|}
\hline No Temuan & \multicolumn{1}{|c|}{ Penjelasan } \\
\hline 20 & $\begin{array}{l}\text { Siswa dapat memperagakan kembali secara benar seperti yang telah diperagakan } \\
\text { oleh guru dalam menggunakan media pembelajaran secara bermakna dan terampil }\end{array}$ \\
\hline 21 & $\begin{array}{l}\text { Rasa puas guru terpancar penggunaan LCD dan Komputer mmenjadikan } \\
\text { pembelajaran sangat efektif, efisien, dan menambah konsentrasi belajar siswa }\end{array}$ \\
\hline Proposisi 5 & $\begin{array}{l}\text { Semangat belajar siswa terfokus saat guru menjelaskan materi pembelajaran } \\
\text { yang menampilkan animasi materi sangat menarik dan mampu meningkatkan daya } \\
\text { serap siswa }\end{array}$ \\
$\begin{array}{l}\text { Semangat dan rasa puas guru terlihat dari daya serap siswa dan konsentrasi } \\
\text { belajar yang meningkat dengan pemanfaatan teknlogi LCD sebagai media } \\
\text { pembelajaran di dalam kelas }\end{array}$ \\
\hline
\end{tabular}

7. Penuh Ketekunan dalam Mengarahkan Tingkah Laku Seseorang Menuju Keberhasilan

\begin{tabular}{|c|l|}
\hline No Temuan & \multicolumn{1}{|c|}{ Penjelasan } \\
\hline 23 & $\begin{array}{l}\text { Pendekatan interaktif yang beragam terhadap siswa berkebutuhan khusus dan } \\
\text { normal (hal akademik) mampu menciptakan rasa belajar di kelas. }\end{array}$ \\
\hline 24 & $\begin{array}{l}\text { Guru membangun potensi melalui kegiatan ekstrakurikuler (drumband) secara } \\
\text { bersama-sama antara orang tua/ wali murid dan peserta didik }\end{array}$ \\
\hline 25 & $\begin{array}{l}\text { Keakraban guru dengan wali murid secara konsisten mampu mewujudkan misi } \\
\text { pendidikan yang berkualitas }\end{array}$ \\
\hline Proposisi 6 & $\begin{array}{l}\text { Ketekunan dan kesabaran Guru mampu meningkatkan kesulitan dalam belajar } \\
\text { siswa menyelesaikan tugas/soal yang diberikan }\end{array}$ \\
\hline & $\begin{array}{l}\text { Ketekunan, kesabaran, dan kerjasama guru dengan masyarakat dapat } \\
\text { meningkatkan kualitas pendidikan dan prestasi siswa baik secara individu maupun } \\
\text { kelompok }\end{array}$ \\
\hline
\end{tabular}


8. Kemampuan menetapkan strategi (merencanakan) sendiri mewujudkan keinginan dan tujuannya

\begin{tabular}{|c|l|}
\hline No Temuan & \multicolumn{1}{|c|}{ Penjelasan } \\
\hline 27 & $\begin{array}{l}\text { Daya inovasi Guru mampu menyediakan alat dan bahan pengganti praktikum IPA } \\
\text { yang tersedia dilingkungannya. Misal sumber listrik dari buah jeruk dapat } \\
\text { menghasilkan sumber arus listrik. Guru percaya akan kemampuan untuk mencari } \\
\text { alat dan bahan yang dapat dimanfaatkan untuk menggantikan alat peraga yang } \\
\text { sebenarnya dari lingkungan yang ada dan mewujudkannya, sehingga dalam } \\
\text { pembelajaran peserta didik menampakkan suatu kebanggaan akan pembuktian } \\
\text { fenomena dalam pembelajaran IPA. }\end{array}$ \\
\hline 28 & $\begin{array}{l}\text { Praktek listrik magnet dengan menggunakan bahan dari paku, seutas kawat/kabel } \\
\text { listrik, dan batere berhasil memberikan rasa percaya diri siswa untuk dapat } \\
\text { mencontoh dan mencobanya. Dengan motivasi keberhasilan dan kepercayaan } \\
\text { akan kemampuan yang dimiliki guru dapat menerapkan alat peraga hasil dari } \\
\text { kreatifitas dan inovasi yang dapat membuktikan dan menjawab fenomena yang } \\
\text { terjadi sesuai dengan kebenaran konsep IPA yang ada. Kreatifitas ini akan } \\
\text { memotivasi siswa untuk meniru dan mencoba bereksplorasi diri menghasilkan } \\
\text { bentuk-bentuk kegiatan yang sangat beragam }\end{array}$ \\
\hline Pecerdasan guru dalam menciptakan alat peraga yang sangat sederhana mampu \\
memberikan pembelajaran yang inovatif dan bermakna, meningkatkan \\
kepercayaan siswa, dalam membuktikan konsep IPA sesuai dengan fenomena \\
alam yang terjadi.
\end{tabular}

2. Kemampuan Mengambil Inisiatif

\begin{tabular}{|c|l|}
\hline No Temuan & \multicolumn{1}{c|}{ Penjelasan } \\
\hline 5 & $\begin{array}{l}\text { Kegiatan transfer of knowledge dilakukan melalui motivasi belajar, penanaman } \\
\text { nilai (values) melalui kerja kelompok, dan membangun karakter (character building) } \\
\text { melalui kepramukaan. }\end{array}$ \\
\hline 6 & $\begin{array}{l}\text { Kemajuan belajar siswa dipantau pada setiap proses pembelajaran berlangsung, } \\
\text { guru memberikan tugas, bertanya, memberikan tes, dan menilai. }\end{array}$ \\
\hline 7 & $\begin{array}{l}\text { Pemberian bimbingan secara klasikal maupun secara perorangan pada siswa saat } \\
\text { pulang sekolah dan mendapat persetujuan dari sekolah tanpa dipungut biaya }\end{array}$ \\
\hline Proposisi 7 & $\begin{array}{l}\text { Komunikasi dijalin secara aktif antara guru dan wali murid dilakukan setiap } \\
\text { pengambilan rapor siswa ke sekolah yang di prakarsai oleh Komite sekolah yang } \\
\text { membicarakan banyak hal masalah siswa. }\end{array}$ \\
\hline & $\begin{array}{l}\text { Guru tidak hanya menjalankan fungsi alih ilmu pengetahuan (transfer of } \\
\text { karakter (Character building), sehingga proses belajar berjalan lancar }\end{array}$ \\
\hline
\end{tabular}

Berdasarkan proposisi 1-7, maka diperoleh Proposisi Mayor yaitu "Kemandirian Guru adalah keadaan atau sikap dimana seseorang (GURU) percaya akan kemampuannya dan dapat memastikan batasan-batasan yang ada untuk menyelesaikan persoalan pembelajaran dengan bebas, cerdas, bertanggungjawab, kerja keras, tekat, ketulusan hati, dan pikiran yang jernih mampu meningkatkan prestasi “

\section{KESIMPULAN}

Berdasarkan proposisi mayor yang didapat dalam pembahasan, kemandirian seorang guru yang terlihat di lapangan dimana proses belajar mengajar sedang berjalan khususnya bagi guru sekolah dasar lulusan S1 PGSD Universitas Terbuka dipengaruhi oleh faktor percaya diri, kemampuan untuk berhasil, mengatasi segala persoalan , faktor kratifitas, kemampuan untuk berkarya, karsa, rasa, dan cipta, kecerdasan, motivasi berhasil untuk peserta didik. Dengan temuantemuan yang ada dilapangan pada situasi dan kondisi yang berbeda, sikap dan keteladanan guru yang muncul dalam setiap saat mampu memberikan karyanya pada setiap siswa, sekolah, dan masyarakat. Indikator -indikator dan ciriciri dari suatu kemandirian, serta fenomena-fenomena karakteristik kemandirian yang terlihat dilapangan tersebut dapat dilakukan suatu sintesa 
menjadi kesimpulan khusus tentang kemandirian guru sekolah dasar lulusan S1 PGSD Universitas Terbuka, yaitu :

1. Proposisi Mayor Kemandirian Guru adalah keadaan atau sikap dimana seseorang (GURU) percaya akan kemampuannya dan dapat memastikan batasan-batasan yang ada untuk menyelesaikan persoalan pembelajaran dengan bebas, cerdas, bertanggungjawab, serta melalui kerja keras, kebulatan tekat, ketulusan hati, dan pikiran yang jernih mampu meningkatkan prestasi .

2. Kesimpulan Kemandirian Guru adalah suatu rencana rangkaian kegiatan yang dilaksanakan dengan kemampuan dan kepercayaannya sehingga dapat menyelesaikan fenomena pada proses pembelajaran secara bebas dan cerdas serta berkarya, karsa, rasa, dan cipta untuk keberhasilan siswa"

Dari bentuk-bentu kemandirian hasil temuan dilapangan, serta pernyataan proposisi-proposisi, proposisi mayor kemandirian peneliti mencoba untuk memperkuat teori-teori kemandirian yang banyak dikemukakan oleh para ahli, konsep-konsep kemandirian dan yang terkait sesuai dengan peta konsep kemandirian digambarkan sebagai berikut. Kemandirian individu adalah makna dorongan untuk berprestasi dan berkreasi, mendorong menjadi manusia yang produktif dan efisien serta membawanya kearah cita-cita yang diinginkan tanpa meminta bantuan orang lain.

Hasil penelitian ini memberikan implikasi kebijakan Dinas pendidikan Kota Kabupaten Bojonegoro yaitu untuk : Memberikan motivasi kepada guru sekolah dasar (SD) untuk mengembangkan kemandiriannya dalam mengajar dengan meningkatkan keinginan untuk melakukan suatu karya, karsa, cipta, dan rasa yang maksimal atau pengembangan diri yang dapat melebihi prestasi karya orang lain dengan dibantu dan difasilitasi oleh pemerintah.

\section{- Saran}

Berdasarkan hasil penelitian ini, maka dapat disaran kan kepada guru, sekolah, maupun Dinas pendidikan sebagai berikut: Perlu kelengkapan sarana pembelajaran yang berstandar, sehingga guru mampu meningkatkan kemandirian mengajar dengan selalu: (a) Mengembangkan potensi yang dimiliki dan di dorong dengan kemandirian dan motivasi berprestasi yang tinggi untuk dapat mencapai tujuan yang diharapkan; (b) Meningkatkan disiplin mengajar dengan kesadaran dan tanggungjawab yang tinggi untuk mewujudkan visi dan misi Kabupaten Bojonegoro sebagai kotan pendidikan; (c). Meningkatkan kemampuan akademik dan keterampilan baik melalui jalur pendidikan formal amupun pelatihan-pelatiha, membuat karya ilmiah, mengembangkan materi pembelajaran, sehingga kemampuan mengajar akanmeningkat; (d). Meningkatkan komitmen terhadap sekolah ,yaitu dengan mengajar sungguh-sungguh, melibatkan diri pada kegiatan sekolah, meningkatkan loyalitas dan dedikasi untuk kemajuan sekolah; (e). Mengembangkan kemandirian guru yang lebih inovatif dan produktif , sehingga mampu menghasilkan karya-karya yang sangat bermanfaat bagi masyarakat dan bangsa.

Diketahui dalam penelitian ini bahwa kemandirian dan motivasi berprestasi, disiplin mengajar dan kemampuan pedagogis, kepribadian, sosial, dan profesional bagi guru sekolah dasar lulusan S1 PGSD Universitas Terbuka sangat baik, sementara keterkaitan antara kemandirian , motivasi berprestasi , disiplin mengajar dan kemampuan pedagogis dengan kinerja guru sangat positif, penulis menyarankan hal-hal sebagai berikut: (a). Dinas pendidikan hendaknya selalu melalukan pengawasan dan pembinaan kepada guru sekolah dasar (SD) di kabupaten Bojonegoro . (b). Lebih banyak memberikan kesempatan dan bimbingan mengikuti seminar, diklat, wokshop, atau bimbingan teknis untuk meningkatkan kemampuan guru sekolah dasar. (c). Memberi kesempatan memfasilitasi guru sekolah dasar untuk mengikuti seminar, pendidikan dan latihan dengan dukungan dana dan kemudahan perijinan. (d). Memberikan insentif bagi guru ynag 
memiliki prestasi baik dalam lingkup kota maupun tingkat nasional.

\section{DAFTAR PUSTAKA}

Abdullah, I. 2011. Sosiologi Pendidikan. Jakarta: Rajawali Pers

Afiatin, T. 1993. Persepsi Laki-laki dan Perempuan terhadap Kemandirian. Jurnal Psikologi. No. 20 (1), hal 713. Yogyakarta: Fakultas Psikologi UGM.

Ahmadi, A.1991. Psikologi Umum. Semarang : Rineka Cipta

Ali, M. 2005. Psikologi Remaja (Perkembangan Peserta Didik), Jakarta: Rineka Cipta.

Anastasia, H.N. 2009. Hubungan Antara Pola Asuh Demokratis dengan Kemandirian pada Remaja. Jurnal Psikologi. Fakultas Psikologi Universitas Setia Budi Surakarta.Vol.1, No.1.

Antonius. 2002. Pengaruh Kemandirian Terhadap Interaksi Sosial Pada Remaja. Semarang: Universitas Katolik .

Barnadib, I. 1982. "Kemandirian sebagai Kebutuhan Psikologis Pada Remaja". [Online]. Tersedia: http://www.ukele.ac.uk/interact/lili/2 005 /contributions/childs. html. [16 April 2016].

Barnadib, I. 1982. Filsafat Pendidikan.FIK IKIP Yogyakarta.

Barnadib, I. 1996. Dasar-dasar Kependidikan; Memahami Makna dan Perspektif beberapa Teori Pendidikan. Jakarta: Ghalia Indonesia

Bernadette, R \& Latchem, C. 2003. Teacher Education Through Open and Distance Learning. London: Routledge Falmer
Bungin, B. 2015. Metodologi Penelitian Kualitatif. Jakarta: Raja Grafindo Persada

Caroline, H., Schenk, K \& Discenza, R. 2003. Distance Learning and University Effectiveness: Changing Educational Paradigms for online learning. London : INFOSCI

Craib, I. 1994. Teori-teori Sosial Modern. Jakarta:Raja Grafindo Persada

Dwiyanto, A. 1995. Mewujudkan Good Governance Melalui Pelayanan Publik. Yogyakarta:Gadjah Mada University Press.

Dyahnita, A. 2012. Pengaruh Persepsi Siswa Tentang Metode Mengajar Guru dan Kemandirian Belajar terhadap Prestasi Belajar Akuntasi Siswa Kelas X Program Keahlian Akuntansi SMA Batik Perbaik Purwokerto Tahun ajaran 2011/2012. Skripsi UNY Yogyakarta.html (diakses 21 Aoril 2016

Hamidi. 2004. Metode Penelitian Kualitatif, Aplikasi Praktis Pembuatan Proposal dan Laporan Penelitian.Malang: UMM Press

Hanna, W. 1986. Hubungan antara Asuhan Anak dan Ketergantungan Kemandirian. Disertasi. UNPAD. Bandung.

Haris, M. 2008. Belajar Mandiri. Surakarta: UNS Press.

Hidayati, I.A. 2012. Implementasi Pendidikan Kemandirian dan Manajemen Diri Santriwati (Studi Kasus Di Kuliyyatul Mu'allimat AlIslamiyah Pondok Pesantren Putri Ta'mirul Islam Surakarta Tahun Ajaran 2011 - 2012). Naskah Publikasi: Universitas Muhammadyah Surakarta.

Hilary, P \& Lentell, H. 2004. Policy for Open and Distance Learning. London: Routledge Falmer 
Hoselitz, B.F. 1988. Panduan Dasar IImuIImu Sosial. CV Rajawali.Jakarta.

Hope, H \& Guiton, P.2006. Strategies for Sustainabel Open and Distance Learning. London and New York:Routledge and Francis.

Iqbal, H. 2002. Metodologi Penelitian dan Aplikasinya. Ghalia Indonesia. Jakarta.

Jaedun, A. 2009. Evaluasi Kinerja Profesional Guru. Makalah.Jaedun@yahoo.com.hal1 -16.html.

Keegan, D. 1986. The Foundation of Distance Education. London : Croom Helm

Masrun, e.al. 1986. Studi Mengenai Kemandirian pada Penduduk dari Tiga Suku Bangsa (Jawa, Batak, Bugis). Laporan Penelitian. Universitas Gajah Mada. Jogjakarta.

Moleong, L.J. 2002. Metodologi Penelitian Kualitatif. Bandung: PT. Remaja Rosda Karya.

Munir. 2012. Pembelaajran Jarak Jauh, Berbasis Teknologi Informasi dan Komunikasi. Alfabeta. Bandung.

Nurul, I. 2012. Wakaf dan Kemandirian Pendidikan (Studi Pengelolaan Wakaf di Pondok Modern Darussalam Gontor Ponorogo). Disertasi. IAIN Wali Songo Semarang http://eprints.walisongo.ac.id/id/epri $\underline{\mathrm{nt} / 15}$

Nuryoto, S. 1993. Hubungan Antara Peran Jenis dengan Kemandirian Siswa SMU.Disertasi (tidak diterbitkan). Yogyakarta: Fakultas Psikologi UGM.

Permen Diknas RI. 2007. Nomor 16 Tahun 2007 Tentang Standar Kualifikasi
Akademik dan Kompetensi Guru. On-Line.

Saifuddin, A. 2005. Metode Penelitian. Pustaka Pelajar. Jogjakarta.

Salmah, L. 2008. Meningkatkan Motivasi Berprestasi, Kemandirian, dan Penyesuaian Diri Karyawan. Jurnal Paedogogia.Vol 11. No. 2. Hal 2232.

Santrock, J.W. 1999. Life Span Development.Seventh Edition. New York: The McGrawHilllCompanies.

Sedarmayanti. 2001. Sumber Daya Manusia dan Produktivitas Kerja. Mandar Maju. Bandung.

Setijadi. 2005. Buku Pedoman Pendidikan Jarak Jauh. Universitas Terbuka. Jakarta.

SK. Mendiknas (2001). No. 107/U/2001. Tentang Pendidikan Tinggi Jarak Jauh.

Sobur, A. 2003. Psikologi Umum. Bandung : Pustaka Setia.

Sujanto, A. 2001.Psikologi Umum. Bumi Aksara. Jakarta.

Suparman, M.A. 2014. Teknologi Pendidikan Dalam Pendidikan Jarak Jauh. Tangerang Selatan: Universitas Terbuka.

Sutopo, H.B. 2006. Penelitian Kualitatif : Dasar Teori dan Terapannya Dalam Penelitian. Universitas Sebelas Maret. Surakarta.

Suyanto, B. 2010. Anatomi dan Perkembangan Teori Sosial. Yogyakarta: Aditya Media.

Syah, M. 2007. Psikologi Pendidikan. Rajawali Pers. Jakarta.

Syah, M. 2003. Psikologi Psikologi Pendidikan Dengan Pendekatan Baru. Remaja Rosdakarya. Bandung. 
Tomei, L.A. 2010. Lexicon of Online and Distance Learning. London: Rowman \& Littlefield Education.

Usman, M.O. 2000. Menjadi Guru Profesional. Remaja Rosdakarya. Bandung.

Wulandari, P. 2012. Pengaruh Kemandirian Belajar dan Kinerja
Mengajar Guru terhadap Prestasi Belajar Akuntansi Siswa Kelas XI IPS SMA Negeri 11 Yogyakarta Tahun Ajaran 2011/2012. Journal Kajian Pendidikan \& Akuntansi Indonesia. Vol 1. No 2.hal 1-28.

Yates, C \& Bradley, J. 2000. Basic Education at a Distance. London and New York: Routledge Falmer. 